\title{
Clinical Profile of Kerosene Poisoning in a Tertiary Level Hospital in Bangladesh
}

\author{
ANWAR S ${ }^{1}$, RAHMAN AKMN ${ }^{2}$, HOUQE SK ${ }^{3}$, MOSHED AKMA ${ }^{4}$, YASMIN L $^{3}$, SALEH ASM $^{5}$, MOHSIN M $^{6}$
}

\begin{abstract}
:
Background: Accidental ingestion of kerosene continues to remain a common medical emergency among children in developing countries. The importance of this poisoning makes it imperative that parents should be aware about this poisoning.

Objective: To see clinical profile of Kerosene poisoning in Bangladesh.

Methodology: This retrospective study analyzed 56 children with acute kerosene poisoning admitted in Dhaka Medical College Hospital from January 2010 to June 2010

Result: Fifty six kerosene poisoning cases were admitted within 6 months period. Among the cases boys 29(51.8\%), aged less than three years 52(93\%), from a rural background 36(64\%) and belonging to lower economic class 51 (91\%) were found. Inappropriate container of kerosene like soft drink bottle 40(71\%) \& summer season 40(71\%) were found major risk factor for kerosene ingestion. Cough 52 (92\%) and dyspnea 51(91\%) were the commonest clinical findings.

Conclusion: Respiratory complaints are predominant clinical features of Kerosene poisoning. Toddler age, children from rural area, summer season were found major risk factors for kerosene ingestion and is mostly due to faulty packing \& storage of kerosene.
\end{abstract}

\section{Background}

Kerosene is a refined oil obtained by distillation and purification of crude petroleum or rock oil. It is a hydrocarbon, used for cooking, heating and lightinga cheap fuel which, due to cultural practices, unfortunately is stored in containers and places, which are accessible to children. Ingestion of kerosene is the important causes of serious accidental poisonings in the developing world. ${ }^{1,2}$ Kerosene has been identified as the most common cause of accidental poisoning in studies on children in South Africa, ${ }^{3}$ West Bengal, ${ }^{4}$ India ${ }^{5}$ and Pakistan. ${ }^{6,1,2}$ Inadequate legislation on the sale of kerosene allows it to be sold in unlabelled containers. ${ }^{7}$

1. Professor. Department of Pediatrics. Dhaka Medical College Hospital. Dhaka.

2. Associate Professor. Department of Pediatrics. Dhaka Medical College Hospital. Dhaka.

3. Assistant Professor. Department of Pediatrics. Dhaka Medical College Hospital. Dhaka.

4. Associate professor, Department of Pediatric Hematology \& Oncology Dhaka Medical College Hospital. Dhaka,

5. Post Graduate Trainee. Department of Pediatrics. Dhaka Medical College Hospital. Dhaka.

6. Assistant Register. Department of Pediatrics. Dhaka Medical College Hospital. Dhaka.

Correspondence: Dr. Sayeeda Anwar
The pattern of poisoning varies in different areas and also with changing times. Aspiration usually occurs at the time of ingestion when coughing and gagging are common, but can result from vomiting after ingestion. Ingestion of even $1 \mathrm{ml}$ of kerosene oil is significantly related to pulmonary complications and more than $10 \mathrm{ml}$ may be fatal.

Low viscosity of kerosene enhances penetration into more distal airways and low surface tension facilitates spread over a large area of lung tissue. Most accidents usually occur due to negligence, parents or the guardian to prevent exposure of the child to harmful substances. ${ }^{8}$ Frequent use of kerosene oil, as for cooking in rural areas and urban slums, low socioeconomic status are the major causes. The underfive age group is main sufferer ${ }^{4-6}$. So early recognition $\&$ intervention is imperative to prevent the life threatening complications of Kerosene poisoning. There is limited research pertaining to clinical profile of Kerosene poisoning in Bangladesh. It was planned to see the clinical profile of Kerosene poisoning which could be a valuable source of policy recommendation $\&$ could raise community awareness. So the objective 
of this study to see the clinical profile of kerosene poisoning in children

\section{Materials and Method:}

It was a retrospective study. Case records including chest radiographs of 56 children with Kerosene poisoning admitted in Dhaka Medical College Hospital from January 2010 to June 2010 were included for this study. From case records data regarding demographic, risk factors for kerosene ingestion and clinical features were collected. Available Chest X-ray those were done after 24 hour of ingestion of kerosene were included in this study. Within the study period April-June were labeled as summer. Collected data were analyzed with the help of software SPSS window version 12. Ethical issues were addressed properly.

\section{Result}

Among the total cases $(n=56) 1-3$ years age group was $93 \%(52 / 56)$ and $3-10$ years age group $7 \%(4 / 56)$. Among the cases $51.8 \%(29 / 56)$ were male and $48.2 \%(27 / 56)$ were female.

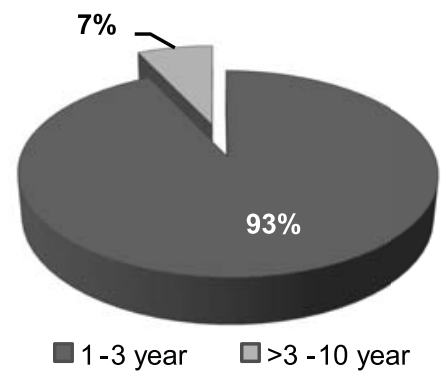

Fig.-1: Age group distribution of the cases $(n=56)$

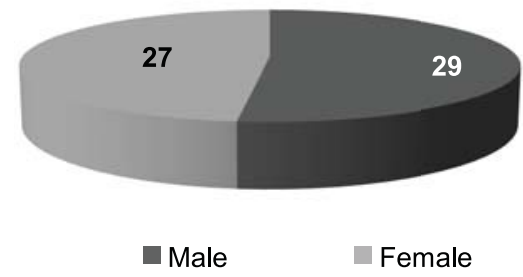

Fig.-2: Gender distribution among the cases $(n=56)$

Among the study population $64 \%$ were from rural area and $91 \%$ were from low socioeconomic status. Soft drinks bottles were used for packing and storage of kerosene in $71 \%(40 / 56)$ cases which is faulty and only in $9 \%$ cases in appropriate container. Seasonal variation of kerosene poisoning occurrence was
January-March 29\% and April-June 71\% showing 2.4 times more kerosene poisoning occurred in summer season as shown in table-I.

Table I

Risk factors for Kerosene ingestion $(n=56)$

\begin{tabular}{lc}
\hline Risk factors & Frequency (\%) \\
\hline Residence & \\
Urban & $20(26 \%)$ \\
Rural & $36(64 \%)$ \\
Socioeconomic status & \\
$\quad$ Middle class & $05(9 \%)$ \\
Lower class & $51(91 \%)$ \\
Packing \& storage of kerosene & \\
Soft drink bottle & $40(71 \%)$ \\
Lamp & $11(20 \%)$ \\
Appropriate container & $05(9 \%)$ \\
Season of the year & \\
Jan-March & $16(29 \%)$ \\
April-June & $40(71 \%)$ \\
\hline
\end{tabular}

Considering clinical presentation 93\%(52/56) were found symptomatic and only $7 \%$ were asymptomatic. Table-II showing cough and dyspnea were the commonest clinical findings in kerosene poisoning. Radiological evidence of pneumonia was found in $30 \%(17 / 56)$ of cases.

Table-II

Clinical manifestation of kerosene poisoning $(n=56)$

\begin{tabular}{lc}
\hline Clinical manifestation & Frequency(\%) \\
\hline Cough & $52(93 \%)$ \\
Dyspnea & $51(91 \%)$ \\
Drowsiness & $27(48 \%)$ \\
Fever & $26(46 \%)$ \\
Vomiting & $19(34 \%)$ \\
Cyanosis & $16(29 \%)$ \\
Abdominal pain & $2(4 \%)$ \\
Bloody stool & $1(2 \%)$ \\
Excoriation of skin & $1(2 \%)$ \\
No symptoms & $4(7 \%)$ \\
\hline
\end{tabular}




\section{Discussion:}

Acute childhood poisoning is a common medical emergency with considerable morbidity and mortality in our country where Kerosene was the commonest form of ingredient to be used. We found that most of the children suffered from this poisoning were ranging from 1 to 3 years age group which is similar with Rashid et al. ${ }^{9}$ This age range of children is probably due to their natural reflexes to put objects into mouth. In this study most of the children came from lower socioeconomic class family that is similar with the study of Mahdi AH. ${ }^{10}$ It was also found that most of the cases occurred in rural areas that may be due to easy accessibility of kerosene. In this study we observed that the accidental kerosene ingestion occurred mostly in April corresponds to the early heat wave of summer, which is similar with the experience of L. Nouri and K. Al-Rahim. ${ }^{11}$ A very striking feature of this study is the usage of empty bottles of soft drink as the container for kerosene is related to the most of the poisoning. This may be due to the childhood conception of soft drink that misleads those babies to drink kerosene from the same type bottles during thirst. Kerosene poisoning commonly occurs due to negligence and unawareness of parents or caregivers regarding kerosene storage in appropriate container and place. Kerosene is a hydrocarbon and the toxicity of kerosene depends upon its contents of naphthenic and aromatic hydrocarbons causing a variety of systemic manifestations. Primarily it results pulmonary complications for which ingestion of even $1 \mathrm{ml}$ is enough. ${ }^{12-15}$ It is also easily aspirated and spread to the lower levels of the respiratory tree resulting bronchospasm and chemical pneumonitis. Again neural tissue, which is rich in myelin, a lipid component is acted upon by kerosene causing central nervous system depression and ventilatory drive suppression. Most of the children in this study, developed cough and dyspnea. Radiological changes were found in $61 \%$ cases by Annobil SH \& Ogunbiyi $\mathrm{OA}^{16}$ though we got $30 \%$ cases in our study. The overall outcome implies the effectiveness of hospital treatment that was also evident by the absent of any death or other systemic complication from acute poisoning. Parents should be warned about storage of Kerosene. So policy may be taken to sell kerosene in the labeled container in rural area to prevent accidental kerosene poisoning in children.

\section{Conclusion:}

Respiratory complaints like cough and dyspnoea are the two most common symptoms in kerosene poisoning. Toddler age, children from rural area, summer season was found major risk factors for kerosene ingestion and is mostly due to faulty packing \& storage of kerosene. Awareness should be build up regarding kerosene storage and policy may be taken to sell kerosene in the labeled container and thereby prevent most of the accidental kerosene poisoning in children.

\section{References:}

1. Meyer S, McAdams AJ, Hug G. Unintentional household poisoning in children. Klin Padiatr 2007; 219: 254-260.

2. Shiamo W, Bucurales JC, Balistreri WF. Paraffin (kerosene)* poisoning in under-five children: a problem of developing countries. Int J Nurs Pract. 2009; 15:140-44.

3. Krug A, Ginsburg CM, Moses SW. The impact of child-resistant containers on the incidence of paraffin (kerosene) ingestion in children. S Afr Med J 2010; 84:730-34

4. Sarker AK,Ghosh S, Barik K. A study of accidental poisoning (in children) in a rural medical college hospital of West Bengal. Indian J Public Health 2005; 34:159-62.

5. Thomas M, Zach MS, Atkinson SD. Profile of hospital admissions following acute poisoningexperiences from a major teaching hospital in south India. Adverse Drug React Toxicol Rev 2000; 19:313-17.

6. Hamid $\mathrm{MH}$. Acute poisoning in children. J Coll Physicians Surg Pak, 2005; 15:805-8.

7. Reed RP, Conradie FM. The epidemiology and clinical features of paraffin (kerosene) poisoning in rural African children. Ann Trop Paediatr, 2007; 17(1):49-55.

8. Woolf A, Wieler J, Greenes D. Costs of poisonrelated hospitalizations at an urban teaching hospital for children. Arch Pediatr Adolesc Med 2009; 151:719-23.

9. Rashid MM, Hasan MA, Chowdhury FR. Childhood acute poisoning in a tertiary medical college hospital of Bangladesh. Mym Med J. 2007; 16:12-14. 
10. Mahdi AH. Kerosene Poisoning in Children in Riyadh. J of Tropical Pediatrics. 2001; 34:316318.

11. Nouri L, Al-Rahim K. Kerosene poisoning in children. Postgraduate Medical Journal. 1998; 46:71-75.

12. Truemper E, Reyes de la Rocha SR, Atkinson SD. Clinical characteristics, pathophysiology, and management of hydrocarbon ingestion: case report and review of the literature. Pediatr Emerg Care. 2004; 3:187-193.

13. Foley JC, Dreyer NB, Soule AB Jr. Kerosene poisoning in young children. Journal of Radiology 2001; 62:817-829.
14. Anas N, Namasonthi V, Ginsburg CM. Criteria for hospitalizing children who have ingested products containing hydrocarbons. JAMA. 1996; 246:840-843.

15. Thalhammer GH, Eber E, Zach MS. Pneumonitis and pneumatoceles following accidental hydrocarbon aspiration in children. Wien Klin Wochenschr. 2005; 117:150-153.

16. Annobil $\mathrm{SH}$, Ogunbiyi OA. Pulmonary radiological changes in kerosene poisoning in the Asir region of Saudi Arabia. Ann Trop Paediatr. 1991;11:391-95. 